(http://www.oldenbourg-link.com/doi/abs/10.1524/ract.2010.1743)

DOI: 10.1524/ract.2010.1743

(http://dx.doi.org/10.1524/ract.2010.1743)

CHEMICAL CHARACTERIZATION OF TIN-LEAD GLAZED CERAMICS FROM ARAGON (SPAIN) BY NEUTRON ACTIVATION ANALYSIS

Javier G. Iñañez ${ }^{1,2 *}$, Robert J. Speakman ${ }^{1}$, Jaume Buxeda i Garrigós ${ }^{2}$, Michael D. Glascock ${ }^{3}$

Radiochimica Acta, 98, 525-531 (2010) 


\title{
Chemical characterization of tin-lead glazed ceramics from Aragon (Spain) by neutron activation analysis
}

\author{
Javier G. Iñañez ${ }^{1,2^{*}}$, Robert J. Speakman ${ }^{1}$, Jaume Buxeda i Garrigós ${ }^{2}$, Michael D. Glascock ${ }^{3}$
}

\author{
1. Museum Conservation Institute, Smithsonian Institution, Suitland, MD 20746-2863 (USA) \\ 2. Cultura Material i Arqueometria Universitat de Barcelona (ARQ|UB), Facultat de Geografia i Història, Universitat \\ de Barcelona, c/ Montalegre, 6-8, 08001, Barcelona (Catalonia, Spain) \\ 3. Research Reactor Center, University of Missouri, Columbia, MO 65211 (USA)
}

\begin{abstract}
Majolica pottery was the most characteristic tableware produced in Spain during the Medieval and Renaissance periods. A study of the three main production centers in the historical region of Aragon during Middle Ages and Renaissance was conducted on a set of 71 samples. The samples were analyzed by instrumental neutron activation analysis (INAA), and the resulting data were interpreted using an array of multivariate statistical procedures. Our results show a clear discrimination among different production centers allowing a reliable provenance attribution of ceramic sherds from the Aragonese workshops.
\end{abstract}

Majolica, Neutron Activation Analysis (NAA), Provenance, Multivariate Statistics, Spain

\section{INTRODUCTION}


Tin-lead glazed pottery, also known as Majolica, is an earthenware pottery characterized by a creamy lightbuff colored ceramic body and an opaque white tin-lead glaze covering the entire outer surface of the vessel. The most characteristic feature of majolica pottery lies in the metallic-oxide decorations that are applied on top of the opaque white glaze coat. The opaque white glaze is composed of sand (e.g., quartz) and lead, which serves as a flux to decrease the temperature needed for melting $\mathrm{SiO}_{2}$. The glaze is opacified with particles of tin oxide $\left(\mathrm{SnO}_{2}\right)$ and also by the action of extant quartz and feldspar inclusions. These inclusions, and the bubbles that result from the firing process, absorb, scatter, and/or reflect incident light, thereby giving the transparent glaze a white appearance. Due to this opacity, decoration is normally applied to the outer surfaces of the glaze coat $[1,2]$.

The antecedents of majolica are found in the early glazed proto-earthenware ceramics of the Middle East, probably in ninth century AD Iraq, although opacified glazed pottery making traditions existed in Mesopotamia as early as the fifth century BC $[3,4]$. The technological knowledge of those original productions, which are likely coarse imitations of Chinese porcelain, was transferred to the Iberian Peninsula by Arabians. From there, majolica technology became widespread throughout the entire Iberian Peninsula during the Middle Ages, even in the New Christian kingdoms and principalities of the North and Northeast. Although an earlier tin-lead glazed earthenware existed, primarily in the Islamic Al-Andalus, the thirteenth century generally is considered the starting point for majolica production in the Iberian Peninsula [5]. Majolica pottery from the Late Medieval Age usually was decorated with black and green motifs over a white background, and this is the most common decoration used by Teruel's craftsmen in their majolica productions at that time, called also Mudejar style. Interestingly, majolica production in Teruel became one of the city's main activity, accordingly to historical documentation and archaeological remains $[2,6]$. Furthermore, majolica from Teruel achieved a high degree of quality during fourteenth century, being an 
important product in the Aragon Kingdom markets, positioned in the eastern part of the Iberian Peninsula [7].

By the sixteenth century, Spanish majolica production flourished as Italian-influenced decorative styles diffused into the Iberian Peninsula. Aragonese majolica also was influenced by the new Italian-influenced decorative trends and styles. Consequently, black and especially green motifs-colors associated with Islamic ceramic traditions-were progressively replaced by blue patterns, sometimes mixed with other colors, such as yellow. In contrast, however, Aragonese pottery producers combined traditional Mudejar motifs, with the new Renaissance influences. This fusion of decorative elements resulted in a distinctive ceramic product. From the sixteenth century until the end of the eighteenth century, the town of Muel and Villafeliche afterwards, became the main production centers in the region of Aragon along with Teruel. Although lusterware production was very important during fifteenth and sixteenth centuries in Muel, majolica decorated with blue on white motifs made in Muel and Villafeliche achieved a relevant impact on Renaissance Spain [8].

In this paper, we summarize the results from compositional analysis of 71 majolica sherds obtained from the three primary production centers located in the Aragon region of present-day Central Spain: Teruel, Muel, and Villafeliche (Figure 1). Ceramics produced at these sites achieved a high importance during the Middle Ages and the Renaissance in the former Aragon Kingdom (Table 1).

Our goal is to obtain a more precise understanding of majolica pottery produced in Aragon. By identifying compositional reference groups for majolica production within the Aragon, we aspire to identify the provenance of majolica that was traded from these sites to outside areas, such as the Valencian, Basque Country, and Catalan markets. 
Although many works have sought to deepen the knowledge, description, and understanding of Medieval and Renaissance Aragonese ceramic productions, most research has been undertaken by art historians or traditional archaeologists. Scientific studies based on the material components of the ceramics themselves are relatively scarce but include thin section petrography [9] and chemical characterization of the paste and glazes [2, 10-16]. Consequently, the present knowledge about tin-lead glazed pottery from Aragon workshops remains uneven and limited.

\section{EXPERIMENTAL}

All of the specimens were sampled from extant museum collections of the Museu de la Ceràmica in Barcelona. (For a more detailed description, pictures and drawings, see [2] -available online at http://www.tesisenxarxa.net/TDX-0205107-115739/). Our sampling strategy was strictly focused on kilnrelated materials to maximize the probability that the materials included in this study were a product of their respective workshops and production centers. For consistency, we focused on ceramics from archaeologically and historically-documented majolica kiln dumps.

In the present study, $10 \mathrm{~g}$ of each collected sample was powdered using a Spex Mixer (mod. 8000) tungsten carbide cell for 12 min. Prior to grinding, glazes and exterior surfaces were mechanically removed by means of a tungsten carbide abrading tool, leaving only the inner part of the ceramic for analysis. This step served to minimize contamination of the ceramic matrix by glaze and soil. Powdered specimens were stored in polyethylene vials for transport to the laboratory. 
Chemical analyses were conducted by neutron activation analysis (NAA) at the University of Missouri Research Reactor's Archaeometry Laboratory (MURR). Prior to weighing, the powdered pottery samples were oven-dried at $100^{\circ} \mathrm{C}$ for at least $24 \mathrm{~h}$. Approximately $150 \mathrm{mg}$ of sample was weighed in small polyvials used for short irradiations. At the same time, $200 \mathrm{mg}$ of each sample was weighed into highpurity quartz vials used for long irradiations. Along with the majolica samples, reference standards of SRM-1633a (coal fly) and SRM-688 (basalt rock) were prepared, as well as quality control samples of SRM-278 (obsidian rock) and Ohio Red Clay ([for analytical conditions see 17]).

At MURR, INAA of pottery consists of two irradiations and a total of three gamma counts. Short irradiations involve a pair of samples being transported through a pneumatic tube system into the reactor core for a $5 \mathrm{~s}$ neutron irradiation using a thermal flux of $8 \times 10^{13} \mathrm{n} \mathrm{cm}^{-2} \mathrm{~s}^{-1}$. After $25 \mathrm{~min}$ of decay, the samples are counted for $720 \mathrm{~s}$ using a high-resolution germanium detector. This count yields data for nine short-life elements: Al, Ba, Ca, Dy, K, Mn, Na, Ti, and V. For the long irradiation, bundles of 50 or 100 of the encapsulated quartz vials are irradiated for $24 \mathrm{~h}$ at a flux of $5 \times 10^{13} \mathrm{n} \mathrm{cm}^{-2} \mathrm{~s}^{-1}$. Following the long irradiation, samples decay for seven days, and then are counted for $1800 \mathrm{~s}$ (known as "middle count") on a high-resolution germanium detector coupled to an automatic sample changer. This middle count yields determination of seven medium half-life elements: As, La, Lu, Nd, Sm, U, and Yb. After additional twoweek decay, a second count for $9000 \mathrm{~s}$ is carried out on each sample. This final measurement allows quantification of 17 long-life elements: Ce, Co, Cr, Cs, Eu, Fe, Hf, Ni, Rb, Sb, Sc, Sr, Ta, Tb, Th, Zn and $\operatorname{Zr}[17]$.

Statistical analysis of the data followed Aitchison's approach and Buxeda's observations on compositional data [18-21]. The statistical procedure consists of the use of ratios of base-10 logarithms of ratios obtained by dividing all the components, in this case the chemical elements, by the element that introduces the 6 
lowest chemical variability to the entire set of specimens. The use of logarithms compensates for differences in magnitudes between major elements, such as $\mathrm{Al}$ and $\mathrm{Fe}$, and trace elements, such as the lanthanide and rare earth elements (e.g. La, Ce, Sm, etc.). Additionally, log-transformed data can sometimes highlight possible perturbations in the chemical data as a result of diagenesis, contamination, or other alteration processes [20].

Data were examined using an array of multivariate statistical procedures. The application of multivariate statistical techniques to NAA data facilitates identification of compositional groups. The similarity between specimens, and subsequently to their hypothetical provenance according to the provenance postulate [22], was examined using Principal Components Analysis (PCA), whereas Canonical Discriminant Analysis (CDA) was performed to assess the archaeological classifications and the chemical groups shown by PCA.

Although sample preparation was conducted under great care to minimize the analytical error, the potential for contamination exists nonetheless and a conservative approach to data interpretation is warranted. For example, cobalt had to be removed from consideration during the statistical treatment because the tungsten carbide cell used to grind the samples exhibits traces of Co in its chemical composition (cobalt is a known binder in tungsten alloys). Additionally, Ni concentrations were below detection limits for many of the samples and subsequently were removed from consideration.

Conversely, given that most of the specimens had also been previously analyzed by X-ray diffraction [2], it has been possible to observe that a relevant number of the analyzed majolica sherds from Muel and Villafeliche exhibited a double process of alteration and contamination (Table 3). This process occurs with the leaching of potassium and, sometimes, rubidium, from the matrix, with a subsequent enrichment of sodium because of analcime crystallization [2, 23, 24]. Because these alteration and contamination 7 
processes affect those components in the matrix composition, without any possibility of calculating a satisfactory correction, $\mathrm{Na}, \mathrm{K}$, and $\mathrm{Rb}$ were removed from consideration during the statistical analysis.

\section{RESULTS AND DISCUSSION}

The variability of each chemical component was first taken into account in this study and assessed by calculating the variation matrix using the S-plus software [25], which provides information about those components that introduce higher variability to the data set. As has been pointed out by Buxeda [20], the variation matrix gives a measure of the variability in the covariance structure, i.e. the total variation (vt). Therefore, when the component $i$ is used as divisor in the logratio transformation, since $\mathrm{vt} / \tau_{\mathrm{i}}$ is actually the trace of the logratio transformed covariance matrix $\left(\tau_{\mathrm{i}}=\operatorname{tr}\left(\Sigma_{\mathrm{i}}\right)\right)$, and this value is always higher than that of total variation, $\mathrm{vt} / \tau_{\mathrm{i}}$ can be considered the percentage of $\operatorname{tr}(\boldsymbol{\Sigma})$ explained by the total variation in the logratio transformed covariance matrix. The subtraction $1-\left(\mathrm{vt} / \tau_{\mathrm{i}}\right)$ being the variability imposed on $\Sigma_{\mathrm{i}}$ by the component $\mathrm{x}_{\mathrm{i}}$ due to its special role in this asymmetric logratio transformation. The higher this value is, the higher is the variability that such component introduces in the covariance structure. Consequently, the elements As and $\mathrm{Sb}$ were removed due to their high variability $\left(\mathrm{vt} / \tau_{\mathrm{i}}<0.35\right)$, which is presumably provided by possible contamination processes during burial, such is the case of As. In addition, Sb is known to be a contaminant of $\mathrm{Sn}$, an important component of majolica glazes. Therefore, higher Sb concentrations are likely diffused into the clay matrix. As mentioned above, $\mathrm{Rb}, \mathrm{K}$, and $\mathrm{Na}$ were removed because they are involved in the previously cited alteration, consequently exhibiting high chemical variability too. In addition, Tb was also removed from consideration due to poor analytical precision. Following the exclusion of these elements, a base-10 logratio transformation was applied to the following subcomposition: $\mathrm{La}, \mathrm{Lu}$, 
Nd, U, Yb, Ce, Cr, Cs, Eu, Fe, Hf, Sc, Sr, Ta, Th, Zn, Zr, Al, Ba, Ca, Dy, Mn, Ti and V, using Sm as divisor because it introduces the lowest variability to the data set $\left(\mathrm{vt} / \tau_{\mathrm{i}}=0.997\right)($ Table 2$)$.

The results are summarized in the Figures 2 and 3, and Table 3. An examination of a bivariate plot using as axis the two first principal components calculated using the latter subcomposition, and accounting for $75 \%$ of the variance, facilitated the identification of five discrete chemical reference groups from the primary production centers of Aragon: Villafeliche, Muel-1, Muel-2, Teruel-1 and Teruel-2 (Figure 2). A closer examination of the PCA results allows identifying two superstructures, clearly linked to the nature of the pastes used for making the ceramics. On one side, the chemical groups of Villafeliche, Muel 1 and Muel 2 are placed, comprising those ceramics that exhibit buff pastes. Chemically, buff paste ceramics show relevant differences especially on their Ca amounts, twice higher than red pastes (Table 3). According to Molera et al. [26], Ca-rich ceramics fired in oxidizing conditions usually show creamy colors, which are related to the decomposition of calcite, a significant development of pyroxenes, and to the low presence of iron oxides. In addition, the Villafeliche chemical group also exhibits discriminating values on its $\mathrm{Sr}$ and $\mathrm{U}$ components, allowing a clear gap on the graphical representation between the different groups. On the other side, ceramics made of red pastes occur on the right side of the plot, loaded by Fe and Cs. Red pastes group comprises both chemical groups found among the productions of Teruel, which its productions are characterized by intense red pastes low in Ca (Table 3). Lastly, sample MJ0018 which is archaeologically linked to Teruel productions, is not clearly assigned to any of the previous groups.

In order to assess the robustness of the groups identified by PCA, a Canonical Discriminant Analysis was performed over the following subcomposition: $\mathrm{La}, \mathrm{Lu}, \mathrm{Nd}, \mathrm{U}, \mathrm{Yb}, \mathrm{Ce}, \mathrm{Cr}, \mathrm{Cs}, \mathrm{Eu}, \mathrm{Fe}, \mathrm{Hf}, \mathrm{Sc}, \mathrm{Sr}, \mathrm{Ta}, \mathrm{Th}$, $\mathrm{Zn}, \mathrm{Zr}, \mathrm{Al}, \mathrm{Ba}, \mathrm{Ca}, \mathrm{Dy}, \mathrm{Mn}$, Ti and V, using Sm as divisor. Interpretation of the graphical scatter plot of the two first discriminant factors allows confirming the strength of the five groups proposed by PCA.

9 
Furthermore, the same separation between buff pastes and red pastes is also evidenced by CDA. Finally, MJ0018 does not match any of the Aragonese reference groups, thus remaining as unassigned (Figure 3).

Chemically, the Teruel subgroups exhibit subtle differences between themselves, such as higher amounts of $\mathrm{Hf}, \mathrm{Zr}$ and $\mathrm{Mn}$ in sherds of Teruel 1, whereas Teruel 2 shows higher values of $\mathrm{U}, \mathrm{Cs}, \mathrm{K}$ and $\mathrm{Ba}$. In addition, subgroups of Muel also exhibit little chemical differences. Whereas Muel 1 has slightly higher Cs, Fe, Al, Sc and Sr amounts, Muel 2 shows higher concentrations of $\mathrm{Hf}$ and, especially, Zr, which may be related to a richer sandy phase in their pastes (Table 3). These relatively slight chemical differences among groups from the same producing town might be related to different clay beds exploited by the potters, or even to different recipes or clay preparations according to different potting traditions by group of potters in each town.

Finally, the provenance of sample MJ0018 remains ambiguous. Interestingly, the red color of the paste of this sample is not as intense as in the rest of the ceramics from Teruel, which could be related to a higher Ca content than the rest (9.3\% against 6\%) (Table 3). Additionally, the archaeological record of this ceramic suggests a production date of the eighteenth century, whereas the rest of the materials collected from Teruel were made in the fourteenth century. Therefore, it seems plausible that a technological change occurred during the Renaissance in Teruel, resulting in a different paste recipe or different clay sources used by eighteenth century Teruel's potters, as proposed historically [7], which could be reflected in the chemical composition of the newer ceramics, slightly different than the fourteenth century productions. The reasons for these changes in pastes may respond to an intention of obtaining creamier or pinker paste colors for their ceramics. Using creamier pastes instead of reddish would had diminish the quantity of tin oxide and other components used for opacifying the glaze coating of the ceramics, thus saving important amounts of this historically expensive material. 


\section{CONCLUSIONS}

The present study provides evidences for a reliable characterization and further archaeometrical studies on Aragonese majolica. The study of a representative sample of majolica pottery from the three primary production centers from Aragon reveals a clear structure that allows the chemical differentiation of each majolica production center. Besides, two different compositional groups were identified in the centers of Teruel and Muel. These chemical differences within the same producing town might be related to different traditions of paste preparation or recipes, possibly corresponding to different groups of potters. Conversely, potters from Villafeliche seem to have used diachronically the same clay material or recipe for their tinlead glazed ceramics. Finally, this study proves that chemical compositions of the five identified productions of the three towns are very homogeneous. Consequently, for Medieval and Renaissance preindustrial tin-lead glazed pottery production, it should be considered that most of the clays and some other raw materials were provided by the potter's guilds to their union members. Therefore, chemical groups can account for "several" workshops of the same city with just slight chemical differences. As a consequence, diversity of production among workshops in a given production centre may only be traced by their technological differences or similarities. 
Acknowledgments. This work forms part of the project "ARCHSYMB" within the Marie Curie International Outgoing Fellowship for Career Development Program of the European Community PIOF-GA-2008221399, and the TECNOLONIAL (HAR2008-02834) funded by Ministerio de Ciencia e Innovación. Authors also are indebted to the Museu de la Ceràmica de Barcelona for its collaboration providing the samples. Special thanks are extended to Nicole Little for assistance with laboratory work at MURR. The laboratory work at MURR was supported in part by National Science Foundation grant no. 0504015.

\section{References}

1. Molera, J., Pradell, T., Salvado, N., Vendrell-Saz, M.: Evidence of tin oxide recrystallization in opacified lead glazes, Journal of the American Ceramic Society, 82(10), 2871-2875 (1999).

2. Iñañez, J. G.: Caracterització arqueomètrica de la ceràmica vidrada decorada de la Baixa Edat Mitjana al Renaixement dels principals centres productors de la Península Ibèrica: Tesis Doctorals en Xarxa, v. 0205107-115739, Universitat de Barcelona, Barcelona 2007.

3. Mason, R. B., Tite, M. S.: The beginnings of tin-opacification of pottery glazes, Archaeometry, 39, $\mathbf{n}^{\mathbf{0}} \mathbf{1}, 41$ - 58 (1997).

4. Hill, D. V., Speakman, R. J., Glascock, M. D.: Chemical and mineralogical characterization of Sasanian and Early Islamic glazed ceramics from the Deh Luran plain, Southwest Iran, Archaeometry, 46(4), 585-605 (2004).

5. Martínez-Caviró, B.: Cerámica Hispanomusulmana. In Cerámica española, 91 134, (T. Sánchez-Pacheco, ed.), Summa Artis, Espasa Calpe, S.A., Madrid 1997.

6. Álvaro-Zamora, M. I.: Cerámica Aragonesa, Ibercaja, Zaragoza 2003.

7. Vicente, J., ed., 2002, ...Operis terre Turolii: Teruel, Museo de Teruel.

8. Álvaro-Zamora, M. I.: Cerámica Aragonesa. In Cerámica española, 221 - 288, (T. Sánchez-Pacheco, ed.), Summa Artis, Espasa Calpe, S.A., Madrid 1997. 
9. Gerrard, C. M., Gutiérrez, A.: El análisis de secciones delgadas y la caracterización macroscópica de algunas cerámicas medievales encontradas en Aragón, Boletín del Museo de Zaragoza, 7, 133 - 158 (1988).

10. Pérez-Arantegui, J., Larrea, A.: Lustre pottery in inland Spain: analytical study of the ceramic decoration produced in Muel (Aragon) in the $16^{\text {th }}$ Century. In $34^{\text {th }}$ International Symposium on Archaeometry, 531-536, (J. Pérez Arantegui, ed.), Institutición Fernando el Católico (C.S.I.C), Zaragoza 2006.

11. Pérez-Arantegui, J., Ortega, J. M., Escriche, C.: La tecnología de la cerámica mudéjar entre los siglos XIV y XVI: las producciones esmaltadas de las zonas de Teruel y Zaragoza. In Avances en Arqueometría 2005. Actas del VI Congreso Ibérico de Arqueometría, 89-96, (J. Molera, J. Farjas, P. Roura, T. Pradell, eds.), Universitat de Girona, Girona 2007.

12. Pérez-Arantegui, J.: Colours of the Renaissance glazed pottery produced in Aragon (Spain): the cases of Teruel and Muel, Techne, 20, 77-82 (2004).

13. Resano, M., Perez-Arantegui, J., Garciz-Ruiz, E., Vanhaecke, F.: Laser ablationinductively coupled plasma mass spectrometry for the fast and direct characterization of antique glazed ceramics, Journal of Analytical Atomic Spectrometry, 20(6), 508-514 (2005).

14. Molera, J., Vendrell-Saz, M., Pérez-Arantegui, J.: Chemical and Textural Characterization of Tin Glazes in Islamic Ceramics from Eastern Spain, Journal of Archaeological Science, 28(3), 331-340 (2001).

15. Pérez-Arantegui, J.: Características tecnológicas de los esmaltes en la cerámica de Teruel: los primeros esmaltes. In...operis terre Turolii, 207 - 210, (J. Vicente Redón, ed.), Museo de Teruel, Teruel 2002.

16. Pérez-Arantegui, J., Ruiz, E., Castillo, J. R.: La cerámica "verde y negro" de los talleres islámicos de Zaragoza: características tecnológicas de sus recubrimientos, Caesaraugusta, 73, 43 - 47 (1997).

17. Glascock, M. D., Speakman, R. J., Neff, H.: Archaeometry at the University of Missouri Research Reactor and the provenance of obsidian artefacts in North America, Archaeometry, 49(2), 343-357 (2007).

18. Buxeda, J., Kilikoglou, V.: Total variation as a measure of variability in chemical data sets. In Patterns and Process, a Festschrift in honor of Dr. Edward V.Sayre, 185-198, (L. Van Zelst, ed.), Smithsonian Center for Materials Research and Education, Suitland, Maryland 2003.

19. Aitchison, J.: The statistical analysis of compositional data: Monographs on Statistics and Applied Probability, Chapman and Hall, London - New York 1986.

20. Buxeda, J.: Alteration and Contamination of Archaeological Ceramics: The Perturbation Problem, Journal of Archaeological Science, 26(3), 295-313 (1999). 
21. Aitchison, J. A., Barcelo-Vidal, C., Pawlowsky-Glahn, V.: Some comments on compositional data analysis in archaeometry, in particular the fallacies in Tangri and Wright's dismissal of logratio analysis, Archaeometry, 44(2), 295-304 (2002).

22. Weigand, P. C., Harbottle, G., Sayre, E. V.: Turquoise sources and source analysis: Mesoamerica and the Southwestern USA. In Exchange systems in prehistory, 15-34, (T. K. Earle, J. E. Ericson, eds.), Academic Press, New York \& London 1977.

23. Schwedt, A., Mommsen, H., Zacharias, N., Buxeda i Garrigós, J.: Analcime crystallization and compositional profiles - comparing approaches to detect postdepositional alterations in archaeological pottery, Archaeometry, 48(2), 237-251 (2006).

24. Buxeda, J., Mommsen, H., Tsolakidou, A.: Alterations of Na, K and Rb concentrations in Mycenaean pottery and a proposed explanation using X-ray diffraction, Archaeometry, 44(2), 187-198 (2002).

25. MathSoft: S-PLUS 2000. User's Guide, Data Analysis Products Division, MathSoft, Seattle 1999.

26. Molera, J., Pradell, T., Vendrell-Saz, M.: The colours of Ca-rich ceramic pastes: origin and characterization, Applied Clay Science, 13(3), 187-202 (1998). 


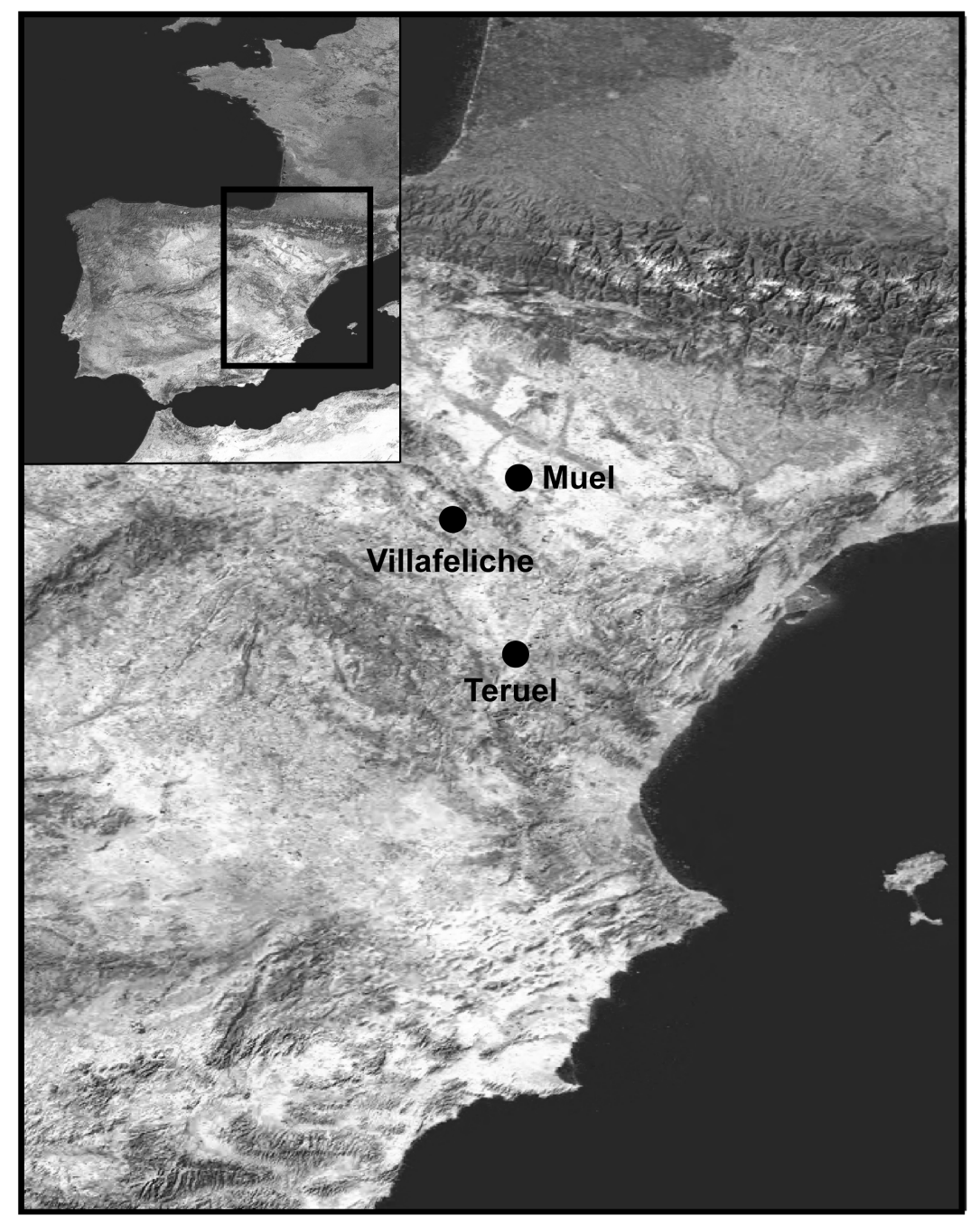

Figure 1. Map of Eastern Iberian Peninsula showing sites discussed in the text and major physiographic features 


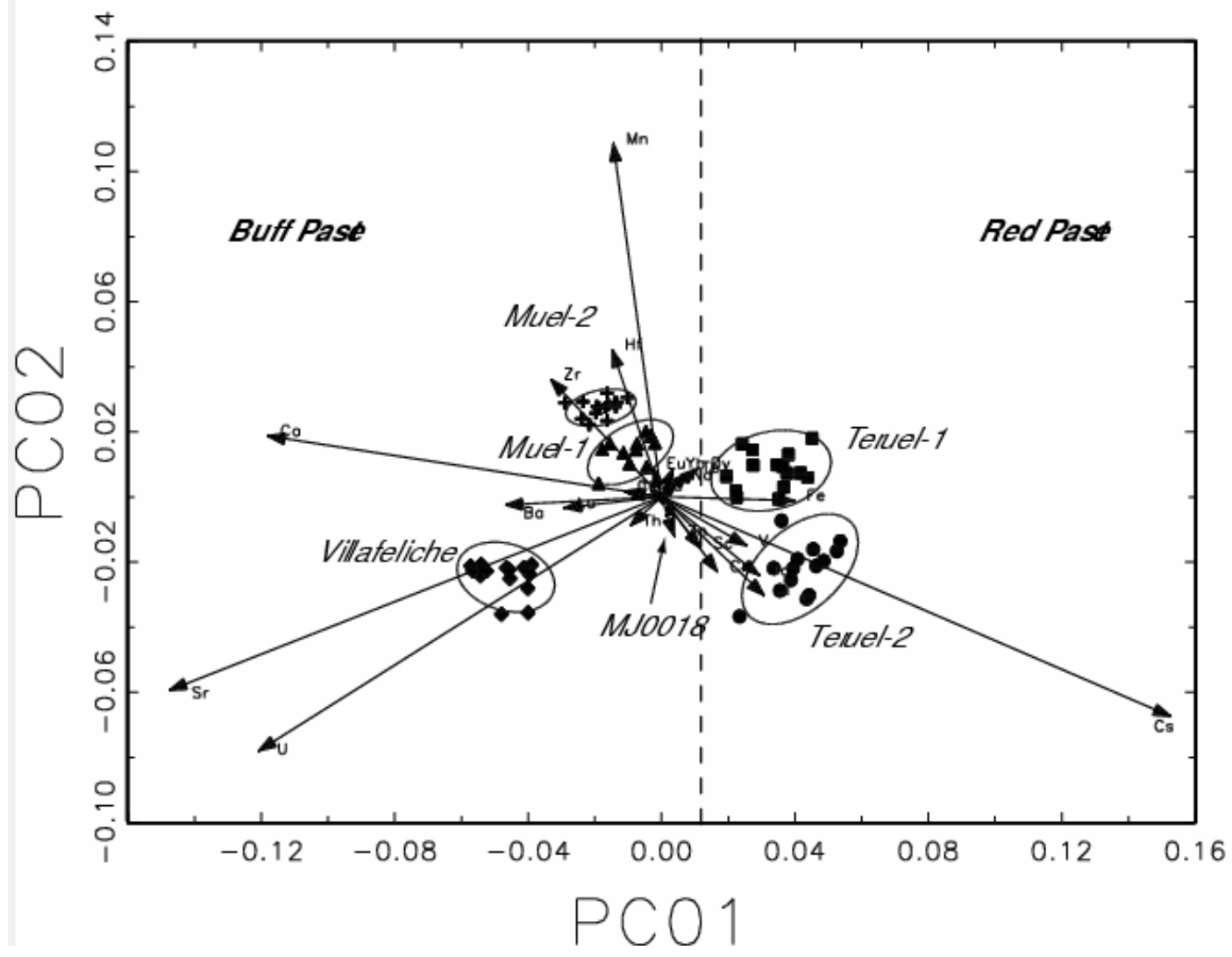

Figure 2. Bivariate Biplot derived from PCA of the variance-covariance matrix of the Aragonese ceramics data. Ellipses represent $90 \%$ confidence level for membership in the groups 


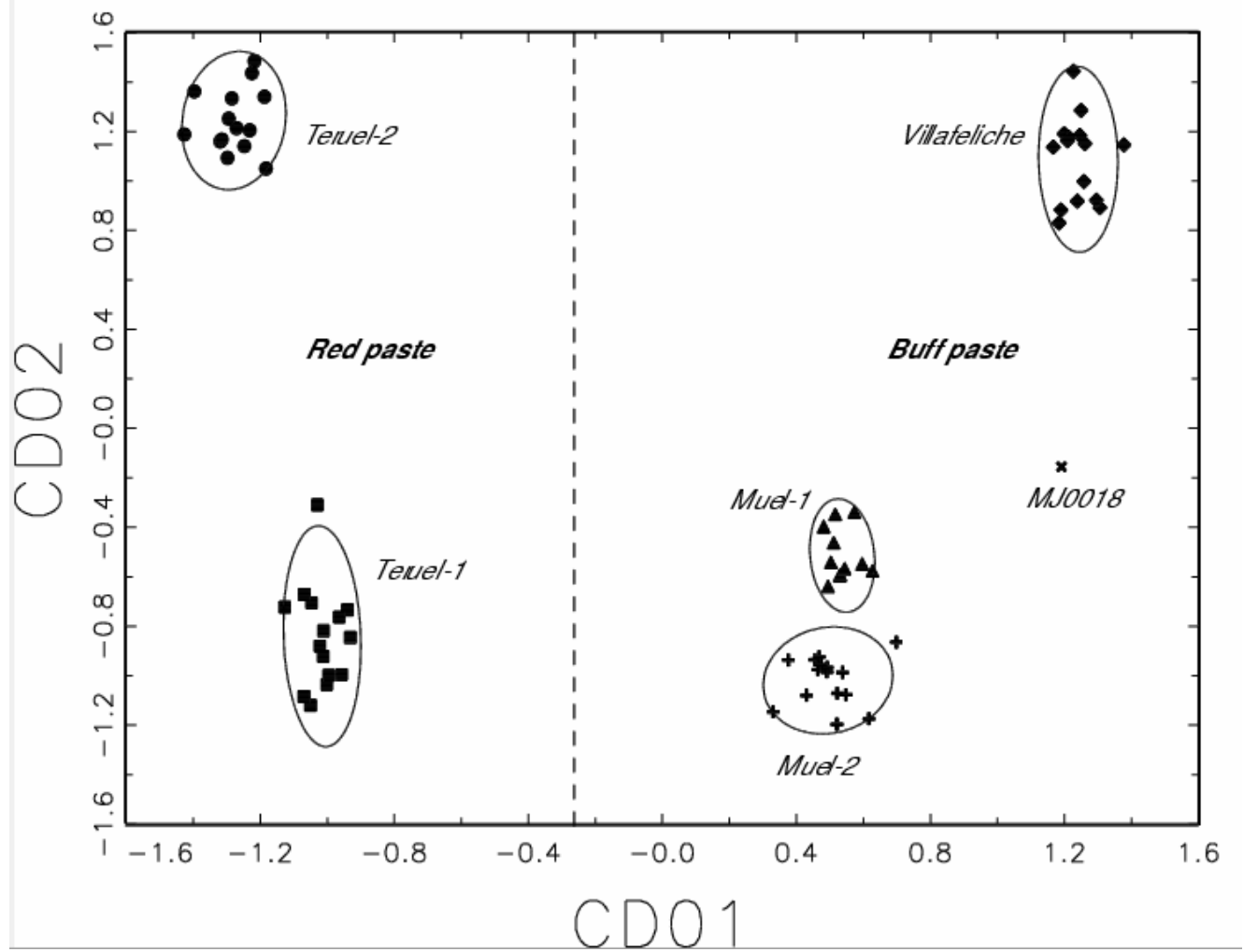

Figure 3. Bivariate Biplot derived from CDA of the Aragonese ceramics data. Ellipses represent $90 \%$ confidence level for membership in the groups 


\begin{tabular}{|c|c|c|c|c|c|}
\hline Sites & Centuries & Green \& Black & Blue on white & Blue \& Green & Total \\
\hline Teruel & 14th & 29 & - & - & 29 \\
\hline Teruel & 18th & - & 1 & - & 1 \\
\hline Muel & $16^{\text {th }}-17^{\text {th }}$ & - & 16 & 10 & 26 \\
\hline Villafeliche & $17^{\mathrm{th}}-18^{\mathrm{th}}$ & - & 15 & - & 15 \\
\hline Total & & 30 & 31 & 10 & 71 \\
\hline
\end{tabular}

Table 1. Specimen classification according to their origin, main decorations, and chronology 


\begin{tabular}{|c|c|c|c|c|c|c|c|c|c|c|c|}
\hline V. Matrix & As & La & $\mathbf{L u}$ & Nd & Sm & V. Matrix* & As & La & Lu & Nd & $\mathrm{Sm}$ \\
\hline$\tau . \mathbf{i}$ & 16.5932 & 1.6493 & 1.9289 & 1.6621 & 1.6033 & $\tau . \mathbf{i}$ & - & 0.717 & 0.930 & 0.752 & 0.693 \\
\hline $\mathrm{vt} / \tau . \mathrm{i}$ & 0.0941 & 0.9465 & 0.8093 & 0.9392 & 0.9736 & $\mathrm{vt} / \tau . \mathrm{i}$ & - & 0.942 & 0.726 & 0.898 & 0.974 \\
\hline \multirow[t]{2}{*}{$\mathbf{r v}, \tau$} & 0.6235 & 0.9991 & 0.9862 & 0.9977 & 0.9989 & $\mathbf{r} \mathbf{v}, \tau$ & - & 0.998 & 0.940 & 0.992 & 0.997 \\
\hline & $\mathbf{U}$ & $\mathbf{Y b}$ & $\mathrm{Ce}$ & $\mathrm{Cr}$ & Cs & & $\mathbf{U}$ & $\mathbf{Y b}$ & $\mathrm{Ce}$ & $\mathrm{Cr}$ & Cs \\
\hline$\tau . \mathbf{i}$ & 5.2474 & 1.7431 & 1.6140 & 1.8942 & 6.6096 & $\tau . \mathrm{i}$ & - & 0.788 & 0.706 & 0.893 & 4.481 \\
\hline$v t / \tau . i$ & 0.2975 & 0.8955 & 0.9672 & 0.8241 & 0.2362 & $v t / \tau . i$ & - & 0.858 & 0.957 & 0.756 & 0.151 \\
\hline \multirow[t]{2}{*}{$\mathbf{r} \mathbf{v}, \tau$} & 0.9015 & 0.9967 & 0.9989 & 0.9813 & 0.7604 & $\mathbf{r} \mathbf{v}, \tau$ & - & 0.985 & 0.995 & 0.931 & 0.911 \\
\hline & Eu & $\mathbf{F e}$ & Hf & $\mathbf{R b}$ & Sb & & $\mathbf{E u}$ & $\mathbf{F e}$ & Hf & $\mathbf{R b}$ & Sb \\
\hline$\tau . \mathbf{i}$ & 1.6070 & 1.9987 & 2.5327 & 3.1594 & 4.6838 & $\tau . \mathbf{i}$ & 0.703 & 1.001 & 1.414 & - & - \\
\hline $\mathrm{vt} / \tau . \mathrm{i}$ & 0.9714 & 0.7810 & 0.6164 & 0.4941 & 0.3333 & $\mathrm{vt} / \tau . \mathrm{i}$ & 0.961 & 0.675 & 0.478 & - & - \\
\hline \multirow[t]{2}{*}{$\mathbf{r} \mathbf{v}, \tau$} & 0.9995 & 0.9550 & 0.9712 & 0.9201 & 0.8040 & $\mathbf{r} \mathbf{v}, \tau$ & 0.997 & 0.864 & 0.916 & - & - \\
\hline & Sc & $\mathbf{S r}$ & Ta & $\mathbf{T b}$ & Th & & Sc & $\mathbf{S r}$ & Ta & Tb & Th \\
\hline$\tau . \mathbf{i}$ & 1.7284 & 5.8008 & 1.9955 & 1.8197 & 1.6383 & $\tau . \mathbf{i}$ & 0.776 & 3.929 & 0.983 & - & 0.710 \\
\hline $\mathrm{vt} / \tau . \mathrm{i}$ & 0.9032 & 0.2691 & 0.7823 & 0.8579 & 0.9528 & $\mathrm{vt} / \tau . \mathrm{i}$ & 0.871 & 0.172 & 0.687 & - & 0.951 \\
\hline \multirow[t]{2}{*}{$\mathbf{r} \mathbf{v}, \tau$} & 0.9887 & 0.8836 & 0.9669 & 0.9955 & 0.9969 & $\mathbf{r} \mathbf{v}, \tau$ & 0.961 & 0.723 & 0.879 & - & 0.996 \\
\hline & Zn & $\mathbf{Z r}$ & Al & Ba & $\mathbf{C a}$ & & $\mathbf{Z n}$ & $\mathbf{Z r}$ & Al & Ba & $\mathbf{C a}$ \\
\hline$\tau . \mathbf{i}$ & 2.1912 & 2.5809 & 2.0367 & 2.5531 & 3.9484 & $\tau . \mathbf{i}$ & 1.154 & 1.441 & 1.005 & 1.465 & 2.590 \\
\hline $\mathrm{vt} / \tau . \mathrm{i}$ & 0.7124 & 0.6048 & 0.7665 & 0.6114 & 0.3954 & $v t / \tau . i$ & 0.585 & 0.469 & 0.672 & 0.461 & 0.261 \\
\hline \multirow[t]{2}{*}{$\mathbf{r} \mathbf{v}, \tau$} & 0.9901 & 0.9686 & 0.9593 & 0.9669 & 0.8632 & $\mathbf{r} \mathbf{v}, \tau$ & 0.959 & 0.884 & 0.857 & 0.848 & 0.605 \\
\hline & Dy & $\mathbf{K}$ & Mn & $\mathrm{Na}$ & Ti & & Dy & $\mathbf{K}$ & Mn & $\mathbf{N a}$ & $\mathbf{T i}$ \\
\hline$\tau . \mathbf{i}$ & 1.7447 & 2.2896 & 3.7725 & 4.1444 & 1.8439 & $\tau . \mathbf{i}$ & 0.800 & - & 2.507 & - & 0.880 \\
\hline$v t / \tau . i$ & 0.8947 & 0.6818 & 0.4138 & 0.3767 & 0.8466 & $\mathrm{vt} / \tau . \mathrm{i}$ & 0.844 & - & 0.269 & - & 0.768 \\
\hline \multirow[t]{2}{*}{$\mathbf{r} \mathbf{v}, \tau$} & 0.9937 & 0.9747 & 0.8517 & 0.9262 & 0.9979 & $\mathbf{r} \mathbf{v}, \tau$ & 0.977 & - & 0.922 & - & 0.992 \\
\hline & V & & & & & & $\mathbf{V}$ & & & & \\
\hline$\tau . \mathbf{i}$ & 2.1699 & & & & & $\tau . \mathbf{i}$ & 1.107 & & & & \\
\hline $\mathrm{vt} / \tau . \mathrm{i}$ & 0.7194 & & & & & $\mathrm{vt} / \tau . \mathrm{i}$ & 0.610 & & & & \\
\hline $\mathbf{r} \mathbf{v}, \tau$ & 0.9764 & & & & & $\mathbf{r} \mathbf{v}, \tau$ & 0.912 & & & & \\
\hline vt & 1.5610 & & & & & vt & 0.676 & & & & \\
\hline
\end{tabular}

Table 2. Compositional variation matrix from the majolica production centers from Aragon. In each column $i(i=1, \ldots, S)$ are the variances after a logratio transformation using the component $x_{\mathrm{i}}$ as divisor, $\mathrm{vt}=$ total variation, $\tau_{\mathrm{i}}=$ total sum of variances in column $i, \mathrm{vt} / \tau_{\mathrm{i}}=$ percentage of variance in the logratio covariance matrix using the component $x \mathrm{i}$ as divisor due to the total variation, $r_{\mathrm{v} \tau}=$ correlation between the values $\tau_{i j}(i$ $\neq j)$ and the corresponding values $\tau_{i}(j=1, \ldots, i-1, i+1, S)$. a: variation matrix calculated without using $\mathrm{As}, \mathrm{Sb}, \mathrm{Tb}, \mathrm{Rb}, \mathrm{K}$, and $\mathrm{Na}$ 


\begin{tabular}{|c|c|c|c|c|c|c|c|c|c|c|c|}
\hline \multirow[b]{2}{*}{ Elements } & \multicolumn{2}{|c|}{ Teruel1 (n=15) } & \multicolumn{2}{|c|}{ Teruel2 (n=14) } & \multicolumn{2}{|c|}{ Muel1 (n=11) } & \multicolumn{2}{|c|}{ Muel2 (n=15) } & \multicolumn{2}{|c|}{ Villafeliche ( $n=15)$} & \multirow{2}{*}{$\begin{array}{c}\text { MJ0018 } \\
\text { composition }\end{array}$} \\
\hline & Mean & $\sigma$ & Mean & $\sigma$ & Mean & $\sigma$ & Mean & $\sigma$ & Mean & $\sigma$ & \\
\hline As (ppm) & 84.90 & 174.01 & 17.94 & 2.00 & 28.39 & 10.16 & 16.65 & 1.61 & 10.13 & 5.52 & 15.28 \\
\hline La (ppm) & 39.79 & 3.22 & 39.13 & 1.53 & 39.99 & 0.99 & 37.98 & 0.85 & 40.03 & 3.37 & 40.93 \\
\hline Lu (ppm) & 0.38 & 0.03 & 0.35 & 0.02 & 0.36 & 0.02 & 0.38 & 0.03 & 0.44 & 0.03 & 0.34 \\
\hline Nd (ppm) & 33.69 & 3.17 & 34.20 & 1.38 & 34.87 & 1.67 & 32.29 & 1.72 & 32.22 & 2.31 & 35.63 \\
\hline Sm (ppm) & 6.75 & 0.53 & 7.00 & 0.26 & 6.91 & 0.16 & 6.59 & 0.13 & 6.82 & 0.27 & 7.07 \\
\hline $\mathbf{U}(\mathbf{p p m})$ & 2.74 & 0.34 & 3.31 & 0.54 & 3.34 & 0.36 & 3.40 & 0.35 & 6.86 & 1.33 & 3.32 \\
\hline Yb (ppm) & 2.95 & 0.22 & 2.78 & 0.15 & 2.72 & 0.08 & 2.78 & 0.08 & 2.77 & 0.20 & 2.51 \\
\hline $\mathrm{Ce}(\mathrm{ppm})$ & 75.17 & 6.24 & 78.60 & 3.21 & 80.11 & 1.93 & 78.18 & 3.35 & 80.90 & 2.48 & 84.42 \\
\hline Co (ppm) & 37.23 & 47.92 & 18.74 & 2.37 & 20.52 & 1.46 & 19.77 & 1.86 & 19.91 & 2.81 & 18.64 \\
\hline $\mathrm{Cr}$ (ppm) & 70.57 & 7.20 & 74.79 & 5.52 & 73.96 & 6.04 & 56.75 & 3.68 & 69.03 & 3.23 & 85.46 \\
\hline Cs (ppm) & 13.11 & 0.95 & 18.47 & 1.21 & 8.03 & 0.40 & 6.53 & 0.29 & 7.29 & 0.66 & 9.11 \\
\hline Eu (ppm) & 1.31 & 0.12 & 1.31 & 0.07 & 1.38 & 0.04 & 1.30 & 0.04 & 1.30 & 0.04 & 1.34 \\
\hline $\mathrm{Fe}(\%)$ & 3.59 & 0.27 & 3.89 & 0.30 & 3.76 & 0.33 & 2.98 & 0.08 & 2.93 & 0.14 & 4.19 \\
\hline Hf (ppm) & 6.83 & 0.39 & 4.94 & 0.26 & 5.32 & 0.31 & 6.93 & 0.28 & 5.86 & 0.32 & 4.65 \\
\hline $\mathrm{Ni}$ (ppm) & 38.28 & 28.60 & 23.61 & 26.32 & 42.47 & 13.45 & 37.57 & 12.19 & 45.97 & 15.71 & 0.00 \\
\hline $\mathbf{R b}$ (ppm) & 131.09 & 9.86 & 221.25 & 13.41 & 132.34 & 6.18 & 115.19 & 4.41 & 162.04 & 11.40 & 173.64 \\
\hline $\mathbf{R b}(\mathbf{p p m}) *$ & - & - & - & - & - & - & 114.43 & 1.97 & 166.11 & 12.03 & - \\
\hline Sb (ppm) & 2.66 & 0.16 & 1.67 & 0.09 & 3.53 & 0.11 & 3.40 & 0.18 & 2.29 & 0.71 & 1.75 \\
\hline Sc (ppm) & 12.75 & 1.21 & 13.71 & 0.95 & 13.37 & 0.57 & 11.10 & 0.29 & 12.69 & 0.63 & 15.34 \\
\hline $\operatorname{Sr}(\mathbf{p p m})$ & 250.19 & 36.06 & 257.40 & 50.79 & 370.55 & 43.35 & 312.93 & 32.66 & 636.81 & 43.15 & 383.28 \\
\hline $\mathrm{Ta}$ (ppm) & 1.22 & 0.08 & 1.54 & 0.05 & 1.17 & 0.04 & 1.13 & 0.04 & 1.19 & 0.04 & 0.98 \\
\hline $\mathrm{Tb}$ (ppm) & 0.91 & 0.10 & 0.92 & 0.09 & 0.85 & 0.05 & 0.89 & 0.07 & 0.84 & 0.06 & 0.82 \\
\hline Th (ppm) & 12.21 & 0.89 & 13.41 & 0.38 & 13.27 & 0.31 & 12.40 & 0.32 & 13.65 & 0.50 & 15.26 \\
\hline Zn (ppm) & 60.45 & 6.59 & 78.62 & 7.11 & 84.09 & 15.98 & 62.66 & 3.45 & 67.11 & 10.73 & 79.70 \\
\hline $\mathrm{Zr}$ (ppm) & 165.66 & 15.93 & 125.31 & 18.55 & 145.41 & 21.94 & 170.69 & 12.74 & 163.81 & 14.35 & 118.16 \\
\hline Al $(\%)$ & 7.57 & 0.58 & 9.52 & 0.52 & 7.89 & 0.29 & 6.51 & 0.20 & 7.43 & 0.46 & 9.99 \\
\hline Ba (ppm) & 363.74 & 48.80 & 505.12 & 41.73 & 588.09 & 65.69 & 531.76 & 46.88 & 541.02 & 43.80 & 656.52 \\
\hline $\mathrm{Ca}(\%)$ & 6.32 & 0.67 & 6.88 & 0.90 & 11.24 & 0.55 & 10.69 & 0.29 & 11.96 & 0.70 & 9.30 \\
\hline Dy (ppm) & 4.96 & 0.45 & 4.80 & 0.17 & 4.62 & 0.23 & 4.63 & 0.26 & 4.49 & 0.27 & 4.64 \\
\hline $\mathbf{K}(\%)$ & 2.22 & 0.25 & 3.38 & 0.16 & 2.65 & 0.24 & 2.50 & 0.18 & 2.79 & 0.23 & 3.48 \\
\hline $\mathbf{K}(\%)^{*}$ & - & - & - & - & - & - & 2.59 & 0.17 & 2.88 & 0.19 & - \\
\hline Mn (ppm) & 449.20 & 60.83 & 350.97 & 46.74 & 642.31 & 82.68 & 574.08 & 36.86 & 335.87 & 21.91 & 507.12 \\
\hline $\mathrm{Na}(\%)$ & 0.17 & 0.04 & 0.19 & 0.04 & 0.30 & 0.09 & 0.27 & 0.04 & 0.20 & 0.05 & 0.16 \\
\hline $\mathrm{Na}(\%) *$ & - & - & - & - & - & - & 0.25 & 0.04 & 0.18 & 0.03 & - \\
\hline $\operatorname{Ti}(\%)$ & 0.39 & 0.04 & 0.38 & 0.02 & 0.39 & 0.04 & 0.38 & 0.04 & 0.40 & 0.03 & 0.24 \\
\hline $\mathrm{V}$ (ppm) & 88.61 & 9.02 & 88.33 & 7.65 & 92.44 & 10.25 & 66.26 & 5.89 & 78.75 & 6.62 & 111.10 \\
\hline
\end{tabular}

Table 3. Mean and standard deviation $(\sigma)$ of the different chemical groups characterized by INAA from 71 majolica sherds from the main production centers of Aragon. All values are expressed as ppm $(\mu \mathrm{g} / \mathrm{g})$ except those expressed as weight $\%$ in brackets. a: mean and standard deviation of $\mathrm{Rb}, \mathrm{K}$, and $\mathrm{Na}$ values of non-analcime altered ceramics 